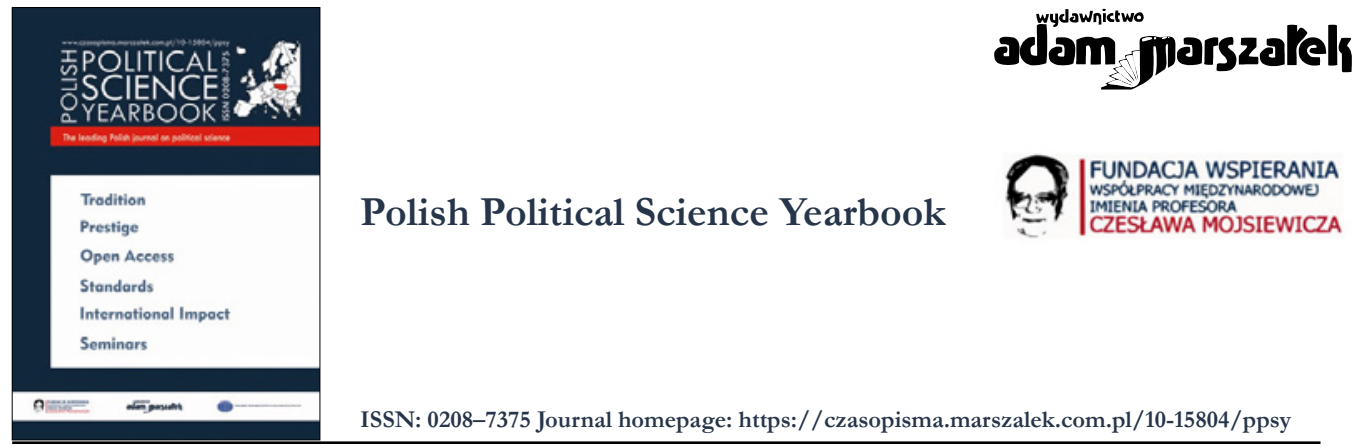

\title{
Persistent Conflict and Perceived Post-Conflict Peacebuilding in Southern Kaduna Region of Nigeria
}

\section{Tunde A. Abioro}

ORCID: 0000-0003-4508-8555

To cite this article please include the following information:

- Journal title: Polish Political Science Yearbook

- Volume number: 50

- Year of publication: 2021

- Published ahead-of-print

Example styles:

[APA Style]: Abioro, T.A. (2021). Persistent Conflict and Perceived Post-Conflict Peacebuilding in Southern Kaduna Region of Nigeria. Polish Political Science Yearbook, 50(issue number), pages. https://doi.org/10.15804/ppsy202129

[Chicago Style]: Tunde A. Abioro, "Persistent Conflict and Perceived Post-Conflict Peacebuilding in Southern Kaduna Region of Nigeria" Polish Political Science Yearbook 50, no. [issue number] (2021).

To link to this article: https://doi.org/10.15804/ppsy202129

Published ahead-of-print

曲 Final submission: 16 June 2021

Published online: 30 June 2021

Printed issue: December 2021

Submit your article to PPSY 


\author{
Tunde A. Abioro \\ Obafemi Awolowo University (Nigeria) \\ ORCID: 0000-0003-4508-8555 \\ e-mail: abiorotunde@gmail.com
}

\title{
Persistent Conflict and Perceived Post-Conflict Peacebuilding in Southern Kaduna Region of Nigeria
}

\begin{abstract}
The cycle of individual and communal lives from birth to death is supposedly preserved by the government through institutions. However, political, social, and economic activities are engaged to make ends meet wherein the government is to serve as an unbiased regulator. The activities that play out in Southern Kaduna reflected politics of being on one side with interplay on origin, identity, religion, and locality. On the other hand, it reflects politics of belonging that play on kin, reciprocity, and stranger status. It has thus resulted in violence, suspicion, and persistent conflict. The study examines citizen's inclusiveness in peacebuilding initiatives and the people's perception of the sincerity of the government. The research relies on secondary sources where governmental and non-governmental publications and documents from relevant and reliable sources enriched the socio-historical approach, particularly those relating to contestation in the region. The study found out that just like situations in the other northwest states of the country, the crisis exacerbates by the government's inability to mediate fairly between warring parties to ensure fairness and justice as well as failure to apprehend and punish the culprits, even as recommendations from the various interventions were unimplemented. Thus, the spate of violence continues.
\end{abstract}

Keywords: conflict, peacebuilding, justice, Southern Kaduna, politics

\section{Introduction}

Since the 1960 independence of the territory known as Nigeria, conflicts and struggle for power have taken different dimensions among the citizenry across regions, and such has constantly played out through religion, politics, and economic contestation, among others. Specifically, the country's northwestern region has witnessed intermittent social challenges resulting in killings, kidnapping and sexual assaults, molestation, night raids, and other atrocities, especially due to ethnic, religious, political, and socio-cultural contestations that 
have long permeated the fabric of the region. Kaduna state - located in the northwestern region, is predominantly agrarian with a high livestock presence and an active farming and trading population with large and several mineral deposits across the state.

Over the past decades, Nigeria's Kaduna state has experienced sharp segregation along religious and ethnic lines precipitated by scores of outbreaks of violence. An estimated 10 000 to 20000 people have lost their lives from 1980 to date (Chatham House Report, 2017, p. 1), with peaks in violent conflict in the KasuwanMagani crisis of 1980, the Gure-Kahugu disturbances of 1984, the Kafanchan conflict of 1987, the Zangon Kataf violent conflict of February and May 1992, the Kaduna violence of February 21, 2000, the Gwantu religious crisis of November 2001 and the brutal killings carried out by herdsmen and farmers among others since 2015.

Unarguably, the state has many conflict manifestations fueled by many factors identified as politically-motivated playing through inter-and-intra-religious, resource struggle related such as land and water-sharing disputes, herders-farmers clashes, government and policy failures, among others (Abioro, 2016). Furthermore, it has led to a rise in criminality and criminal acts (rural banditry, cattle rusting, and kidnappings), as well as a phenomenal increase in social problems such as drug addiction, sexual offenses, unemployment, and other security-related challenges (IPCR, 2017, p. 243).

According to Agagu (2010) and Omotoso (2010), the nature and character of the Nigerian state show a weak structure that has permeated insecurity, poverty, misgovernance, lack of clear vision, and road map to development which constitutes hindrances to development, peace, justice, and reconciliation.

Presently, Kauru, Kachia, Zangon-Kataf, Kaura, kagarko, Jaba, Sanga, Jema'a local governments make up the Southern Kaduna region. Somehow, the region is a cultural area that serves as home to a largely Christian religious group. Due to its marginal status, it is loosely seen and regarded as a second-class community that bears the undertone of social identity, religious affiliation, and cultural heritage. Meanwhile, Abdulbarkindo, Alupsen, and Gloria (2018) expressed that Southern Kaduna has been controversial for many years. While a line of thought opines that it first came into regular use to refer to the southern part of Kaduna state, which officially came into being in 1987, when it was detached from Katsina Province, others insist that the term came into official parlance after 1907 and referred to the districts belonging to the Southern Division of Zaria Province set up by the British colonial administration. This administrative change was caused by the persistent revolt against Muslim-controlled Zaria by the confederation of Christian ethnic nationalities in the area, especially from 1901 onwards when British colonial forces conquered the territory.

The intensity of ethnic resilience, couched in the context of Christian freedom from the alien Islamic inspired forms of control from Zaria, triggered a movement encouraging and bordering on separation. Consequently, "Southern Kaduna" emerged as a socio-political identity encapsulating the struggle against the Muslim Hausa-Fulani hegemony, particularly about religion, politics, and culture. 


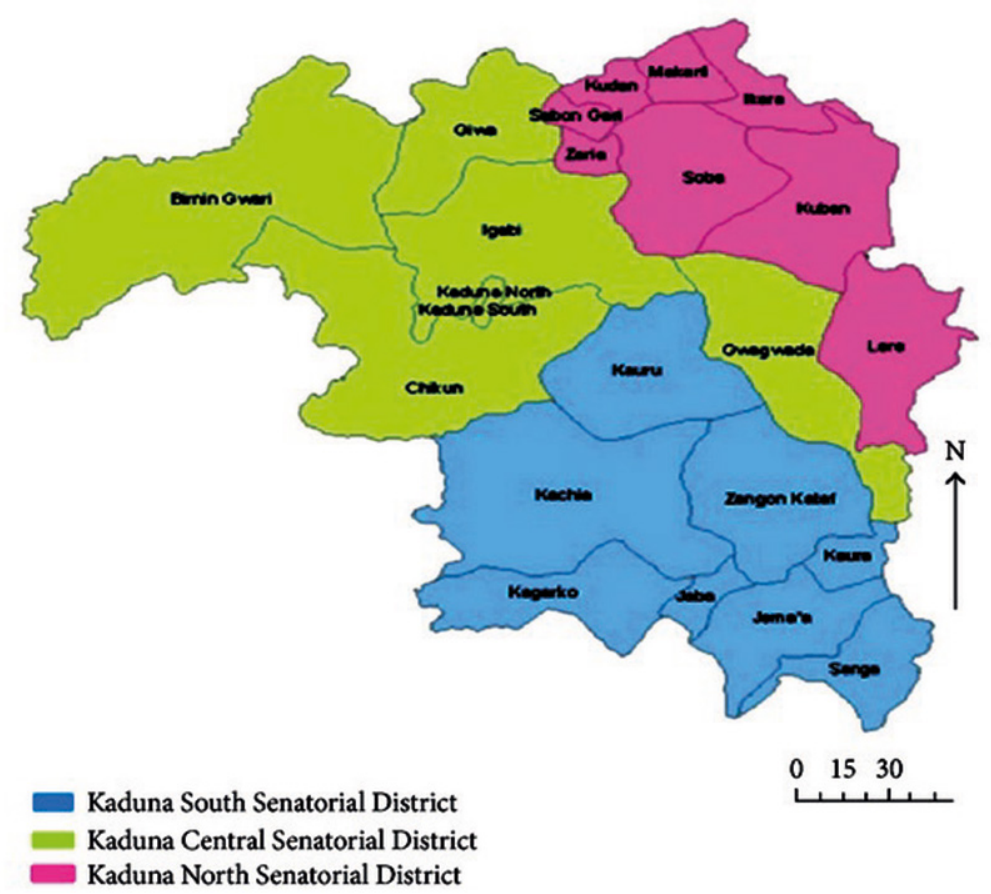

Map 1. Showing the Southern Kaduna Senatorial district and the other senatorial districts of Kaduna State, Nigeria.

Source: http://www.ncocusa.com/constituencies_kaduna.html.

However, in recent times, the conflict dynamics in the southern part of the state have changed from ethno-religious to herders-farmer conflicts and the isolated occasional Shiite clashes and protest in Zaria (Institute for Peace and Conflict Resolution, 2017, p. 243). The conflict has resulted in political tension; loss of lives and destruction of property, including farmlands and cattle rustling; increased polarization of population along religious and ethnic lines; intense fear and insecurity among the citizens; proliferation of light arms and ammunition; high level of banditry and kidnapping among others that has unfortunately remained potent. The study is divided into sections to cover the theoretical basis to understand the foundation of the persistent conflicts, strategies for peacebuilding to address the situation by government, concluding remarks, and recommendations.

\section{Theoretical Foundation}

The concept of peacebuilding came to the limelight in 1970 when a Norwegian scholar Johan Galtung firstly termed peacebuilding through his campaign for a cooperative system that 
would build sustainable peace (United Nations Peace Building Support Office (UNPBSO), 2012). The peacebuilding system aims to address the root causes of conflict and support local capacity for peace management and conflict resolution. Peacebuilding has, since the 1980s, expanded to include several dimensions, such as rehabilitation, disarmament, deradicalization, reintegration, reconstruction, rebuilding governmental, and re-invigorating social, economic, and civil society institutions. Recently, the concept came to the limelight with Boutros-Ghali's landmark article: An Agenda for Peace, published in 1992. Therein, it was defined as a process that facilitates the establishment of durable peace and tries to prevent the recurrence of violence by addressing root causes and effects of conflict through reconciliation, institution building, and political and economic transformation (Peace Building Initiative History, 2017).

The crisis in Southern Kaduna presents itself as recurring over resource sharing and struggle for inclusion in power-sharing within the state. A pillar of the social conflict theory opines that conflict is an inevitable part of human society; thus, the situation in Southern Kaduna is presented. However, conflict does not exist in a vacuum as it is often triggered by a specific factor or combination of factors. The confrontation in Southern Kaduna is subject to the conditions governing conflict because it is the manifestation of existing challenges already inherent in the society. According to Fukuyama (2004), conflict theories, of which the social conflict theory belongs, highlight class, race, and gender conflict as it causes conflict and creates an imbalance in society. Fukuyama's view is relevant as it recognizes that social conflict exists in the realm of the economics of the Southern Kaduna region and that it is also present in other aspects of social interactions that include politics, race, gender, religion, and demographics.

The most prominent proponent of the social conflict theory is Karl Marx. In his work Capital: A Critique of Political Economy (1867), he espoused and highlighted class struggle and historical materialism. The theory captures the issue of social classes and the relationship dynamics within and between these classes. Marx states that capitalism was an unstable socio-economic system destined for chaos as it created a two-class system - the wealthy and poor - and it was inevitable that the poor, who are in the majority, would one day revolt against the system. Marx posits that social violence is a natural reaction to oppression in society. Also, Oberschall (1978) refers to social conflict as a conflict in which the parties aggregate individuals, such as groups, organizations, communities, and crowds, rather than single individuals.

The social conflict theory's relevance can be seen in the context of its applicability to the (dis)proportionate wealth (re)distribution that affects the activities of citizens of Southern Kaduna in which the parties are aware of the incompatibility of potential future positions and in which each party wishes to occupy a position that is incompatible with the wishes of others. As such, social conflict theory presents a useful base for policy influence that has played out in the region. This position is germane to this study because the issue of confrontation over land is primarily an issue of conflict, especially between the indigenous 
farm owners (mixed ethnicities and religious background) who are mostly Christians on one part; and the nomadic or semi-nomadic herdsmen (predominantly Fulani and Muslims) on the other.

The social conflict theory is not without its drawbacks as Wood (1983) and Kolakowski (2005) viewed it as not broad enough to capture the various power structures present in a society as it sees economic relations as the most important factor without considering that there are other crucial social variables that condition the actions of the 'have nots' in the society. It also unfairly plays down the fact that economic competition in society can be beneficial. Furthermore, the 'individual' sense is lost as the theory has no room to analyze how individuals react to circumstances as it affects them.

Meanwhile, Garson (2007, p. 1) identified the historical tension between two rival theories of pluralism and elitism to explain group contests; while the former is responsible for a decentralized form of government wherein interest groups engage in conflict and dialogue; group interests are multiple and shifting, and the democratic process of election resolves any inequalities of power or access created by disparate resources. The latter holds that a small minority comprises members of a socio-economic elite and policy group that hold the most power and influence in politics and policymaking (Garson, 1978, p. 4).

Ostensibly, the relationship between groups in Southern Kaduna transits to struggle for influence and power; the beginning of group theory is the acknowledgment that the state is composed of both institutional and non-institutional actors that are products of historical, socio-economic, political, and various other concepts that find fault lines in unequal access to power, class, economics and even justice (Kukah, 2017; Garson, 2007). Thus, depicting the relationship between the Hausa Fulani herders and the local farmers whose interests are conflicting. At the same time, the state is expected to act as a mediator and the sole mechanism of control. Evidently, the role of groups affects state actions and interventions to maintain peace as the conflict in Southern Kaduna resonates around the contest for power. Lukes (1974, p. 57) expressed this in three dimensions: the first is the exercise of power which occurs in an observable overt conflict between actors over key issues; the second is the exercise of power, which occurs in observable overt or covert conflicts between actors over issues or potential issues and; the third is the power to shape peoples' references so that neither overt nor covert conflicts exits. On the whole, state mechanism and strength to adjudicate and bring perpetrators to justice is eroded.

\section{Discussion of Findings}

This section shall evaluate tripod issues of concern - resource curse and contest (violent contestation), displacement, destruction, and depletion (effect), as well as the strategies (peace attempts) for peacebuilding in Southern Kaduna. 


\section{Resource Curse and Contest in Southern Kaduna}

Ideologically, Gudaku (2017) expresses that the indigenous people of Southern Kaduna have a long history of marginalization, domination, and slavery dating from Zazzau with Saurata System (1450-1850); Emirate System in 1816-1903 and the Native Authority System from 1903-1930. Similarly, Abdulbarkindo, Alupsen, and Gloria (2017, p. 5) opine that the process of sedentarization by nomads and the indigenous people in the region before and after colonization continued violently with clear intention to conquer territories and convert people to Islam and further states that

the nomadic pre-colonial Islamic movement in Africa was the jihad led by Askia Mohammad I who ruled Songhay Empire (1442-1528); another radical movement led by a nomadic Fulani was the conquest of Ethiopia (Abyssinia) in 1527. Meanwhile, the Fulbe and the Somali herdsmen provided the main fighting forces for Islamic Jihads that were staged in $17^{\text {th }}$ and $18^{\text {th }}$ century in Africa. In the 1670s, Nasir al-Din, a Berber herdsman and Islamic scholar organized a jihad against local communities in Mauritania, forcefully occupying their land and converting many to Islam. Uthman Dan Fodio, the founder of the Sokoto caliphate in northern Nigeria, was himself a descendant of the Fulani herdsmen who promoted Islamic jihad.

Thus, the contestation in Southern Kaduna no doubt has many dimensions and playouts. To conceive of the conflict simply in terms of being a clash of political, economic, and social interests is, at best, reductionist as the ideological factor of the conflict can be linked to the Islamic war of expansion, domination, and supremacy.

Furthermore, the ethno-religious dimension of recent times can be traced to the 1999 assault and aggression against Southern Kaduna Christians. Johns (2011) reveals that residents of Jama'a emirate took the opportunity of the appointment of a new Emir of Jama'a to protest not only this appointment but the entire emirate system that turned into attacks of the Hausa minority and the non-Hausa majority resulting in the deaths of scores of people and the injury of several others. Zwahu (2012) explains that Southern Kaduna people were killed, beaten, massacred, and the Human Rights Watch (2015) describes it as the single worst outbreak of violence in Nigeria since the 1967-70 civil war.

Another main cause of the conflict is the fight for supremacy over the land. Luka (2017) discovers from the report given by Musa Solomon, President of Southern Kaduna Peoples Union, that the quest for Southern Kaduna land, through the creation of grazing reserves, is the cause of the Southern Kaduna crisis. The Southern Kaduna region no doubt has agriculture as the mainstay of her economy, hence, the vegetative nature of her ecosystem. As a result of the global climate change that heightened drought and other natural factors, the herdsmen experience a scarcity of green vegetation to feed their cattle. Thus, resort to moving the cattle to graze on the farmlands of the indigenous people, the resistance to the 
grazing by farm landowners have resulted in severe attacks with both herders and farmers having casualties.

Also, Luka explains there is land expropriation of indigenes to the Fulani of Southern Kaduna while resistance leads to being killed or chased out. It has translated to perpetual intimidation to dislodge the helpless indigenous people of the region.

Evidently, most crises in Southern Kaduna start with land disputes before degenerating into a full-blown ethno-religious war. The 1987 burning down of the College of Education Kafanchan over the headship appointments by the State government in the institution of learning signaled the hatred between the Christians and Muslims in Kaduna. Zwahu (2012) notes that the Muslim Students Society attacked students of the College of Education, hence escalating the crisis along religious lines. Ajunwa (2011) reports that the crisis at the College of Education spread to other parts of the state leading to the burning of places of worship, with many lives and properties worth millions of naira lost. Consequently, in 1992, the Zango Kataf Crisis catalyzed the hike in killings in Southern Kaduna. The Zangon Katab has the Atyap as the dominant ethnic group. The Zango Kataf crisis was bloody on February 6 and May 15-16, 1992 (Uroko, 2018). Also, the attempt to introduce Sharia in Kaduna State led the Kaduna branch of the Christian Association of Nigeria (CAN) to organize a public protest that degenerated into fatal clashes between the two major religious groups with massive violence and destruction on both sides. An accurate, total death toll has never been ascertained, and as is typical in these situations, government and police officials were keen to underreport figures (Gudaku, 2017; Johns, 2017).

It should be clear that the history of Southern Kaduna is a struggle for domination. It is full of intrigues and conspiracies laying claim to ownership of land and other natural resources, indigenous and socio-political rights, and rights of traditional leadership, to mention but a few of the areas of potential conflict between Hausa-Fulani Muslims and indigenous Christians. Thus, due to the socio-political and cultural background to the history of "Southern Kaduna", this term carries a whole range of undertones concerning social identity, religious affiliation, cultural heritage, economic opportunities, and geographical location. Therefore, it is little wonder that some regard "Southern Kaduna" as a cultural area and Christian religious group. However, for others, it refers to a subordinate community, an economic and political minority zone. Due to its marginal status, it is seen as a second-class community. Again, others view "Southern Kaduna" as a geographical entity and region with a unique, large, fertile environment conducive for arable and livestock farming. Thus, the natural resources available in this region cause it to be permanently under contestation (Abdulbarkindo, Alupsen, and Gloria, 2018).

\section{Displacement, Destruction, and Depletion of Southern Kaduna}

Kaduna's Hausa-Fulani residents are mostly Muslim and are the majority in the northern half of the state, while the people of Southern Kaduna are predominantly Christian, although they 
still have tribal and lingual differences. History holds a perception of suppression socially, politically, and economically by the Hausa-Fulani people. Evidently, lack of quality education, inadequate social infrastructures such as hospitals, roads and water system, lack of development, political exclusion and elite capture has weakened the traditional establishment. The Africa Conflict and Security Analysis Network (ACSAN) reports that in four local governments of Jema'a, Kuara, Kauru, and Sanga between May 2016 and September 2017, 3678 lost properties while 3314 were displaced. The same period recorded 130 people were injured in three local governments of Jema'a, Kaura, and Sanga. Although the number of casualties cannot be ascertained, literature puts it at well over 10000 in the last two decades.

In 1981, recorded clashes in Adara; the 1986 opposition to Muslim candidate led to clashes in Lere, and post-election fighting of 1992 witnessed the Zangon-Kataf massacre that recorded thousands of deaths; 1998 ethno-religious confrontations; 2000 anti-Sharia protest; and 2011 post-election violence, among others. Also, the 2016 Southern Kaduna massacre, which some non-governmental organizations have titled genocide against Southern Kaduna indigenes. Uche (2016) narrates that the Catholic Archdiocese of Kafanchan claimed 808 lives, fifty-three villages have been attacked, and 57 people severely injured. However, the Miyetti Allah Cattle Breeders Association, the umbrella organization of herdsmen, notes that the group said it had lost no fewer than 6000 cows to the crisis in Southern Kaduna. The group faulted claims by independent bodies that the indigenes of southern Kaduna were the sole victims of the ongoing conflicts (Uroko, 2018).

The pattern of violent conflicts in Southern Kaduna has had a long history. It is intimately tied to struggles for power and political representation, socio-cultural expression, and economic opportunities linked to employment and natural resource management (Kukah, 2017, p. 6), which unfortunately has led to the rise of ethnic militia and an increase in smuggling small and light weapons.

\section{Strategies for Peacebuilding in Southern Kaduna}

Peacebuilding is an effort of humanitarian assistance in its differing contexts. It sounds truism because the concept is meant to rebuild the collapsed communities, groups, institutions, and infrastructures of nations torn by civil war and strife. The concept aims to unite groups, communities, and institutions formerly at war or civil unrest with bonds of peaceful mutual benefit. Peacebuilding is an organized effort aimed at uprooting the deepest causes of conflict. In this regard, the exercise of peacebuilding is an inclusive one. It addresses all phases of conflict by strengthening the techniques for the institutionalization of peace (Lamidi, 2019).

Issues of conflict prevention, resolution, and peacebuilding are essential for development initiatives. Peacebuilding is a key component of all global development targets, leading deliberations at the World Humanitarian Summit. Kukah foundation (2017, p. 25) identifies various attempts and interventions to include the federal government special security task 
force (Operation Harbin Kunnama), federal Senate Ad-hoc committee, and state government peace and reconciliation committees. Also, the Kafanchan Peace Declaration signed by key stakeholders on March 23, 2016, with recommendations on conflict prevention, long-term arbitration, and mediation mechanisms, will facilitate the healing process if properly executed.

Since the onset of the crises in the 1980s, over 30 interventions either by the federal or state governments at various times have been proposed in the form of mechanism, techniques, legislation, and commissions to restore peace and harmony in the affected regions by the government and other institutions. Some of the attempts to bring under control the persistent crises include the Judicial commissions, White Papers, Reports and recommendations of previous committees and Commissions which include: the White Paper on the Report of the High-powered Administrative Committee on Land Use: Issuance of Certificates of Occupancy and Layouts in Kaduna Township From October 1, 1979 - December 31, 1983, 1984; Kaduna State Grazing Reserves Law, Kachia State Grazing Reserves Law of 1987; White Paper on the Report of the Committee to Investigate Causes of Riots and Disturbances in Kaduna State, March 6-12, 1987; Justice Dalhatu Ja' afaru Commission of Enquiry set up by Kaduna State Government, 1990; Kaduna State Grazing Reserves Law (Cap 62, 1991). The Gayam Grazing Reserve Order Law, 1997; White Paper on the Report of the Judicial Commission of Inquiry into the Kaduna State Religious (Sharia) Disturbances of February 2000; Report of the Kaduna State Peace and Reconciliation Committee, 2013; Judicial Commission of Inquiry into the ongoing violent crises in Kajuru local government area of the state, established by Governor of Kaduna State, on April 25,2019. Despite all the peace attempts, the Southern Kaduna people feel neglected as there has not been timely prosecution or adequate compensation, which has, over time, raised suspicion among the citizens about the genuineness of the peace interventions of the government. The government's response has been merely reactionary and not responsive, bringing a few stakeholders to the roundtable after attacks have been carried out.

\section{Recommendations}

Due to lack of proper prosecution and adequate compensation, the perception of lack of inclusiveness is high among the people of Southern Kaduna. Among other recommendations, the government should timely prosecute suspects, punish offenders with the instrumentality of the state's statutory laws and regulations, and evolve more productive schemes to engage all the identified stakeholders and strengthen traditional and alternative dispute resolution mechanisms. Also, the government should uphold social justice, equity, and respect for the rule of law to ensure sanity and respect for human lives and property. 


\section{Conclusion}

The conflict situation in Southern Kaduna plays out mostly between Hausa-Muslims and the indigenous Christians who compete for economic survival. The region has passed through a period of seemingly resource curse and violent contestation, persistent displacement, destruction, and depletion. Unfortunately, the peace attempts were not productive, as evident in subsequent interventions where terms of reference do not change, and worst still, recommendations of previous attempts were not implemented.

The indigenous people of Southern Kaduna not only feel excluded from partaking but also sidelined in the control and spoils of politics of the state; holds the perception of social neglect as well as depression and worst still presently confronted with threats of extinction on the lands that not only provide economic sustainability but retain historical attachment.

Unfortunately, the attitude of governments over the crises in Southern Kaduna has shown carelessness and negligence. It is inexplicable that after several decades, the government still engages in setting up judicial commissions with the same terms of reference, that is, to investigate, ascertain, and identify remote and immediate causes of crises in parts of Southern Kaduna. Still, individuals, traditional and religious institutions are elusive of clear strategies and initiatives to permanently address the contestation. Thus, genuine peacebuilding remains an illusion.

\section{References:}

Abdulbarkindo, A., Alupsen B., and Gloria, C. (2018). Nigeria: Southern Kaduna and the atrocities of Hausa-Fulani Muslim herdsmen (May 2016 - September 2017) Volume 1. Open Doors International / World Watch Research Unit, Working Paper, 6, 1-35.

Abioro, T. (2016). Politics of Inter Ethnic and Religious Conflicts in Nigeria: The Case of Jos, Plateau State Revisited, Review of Nigerian Political Economy. Journal of the Department of Political Science and International Relations, 5(1\&2), 29-41.

Agagu, A. (2010). Public Policy Instability and Political Instability in Nigeria. The University of Ado-Ekiti Press, 23rd Inaugural Lecture.

Bonnat, Z. (2012, June 24). Contemporary ethnic and Religious Crises in Kaduna State. Vanguard Newspaper. www.vanguardnewpaper.com

Centre for Humanitarian Dialogue. (2016). The Kafanchan Peace Declaration. Centre for Humanitarian Dialogue: Mediation for Peace.

Gabriel, J. (2019, April 16). Kajuru killings: High Court Judge Heads Commission of Inquiry. Daily Post Nigeria.https://dailypost.ng/2019/04/16/kajuru-killings-high-court-judge-heads-commission-inquiry/ Garson, G. (1978). Group Theories of Politics. Sage Publication.

Garson, G. (2007). Group Theories of Politics. Sage Publication.

Gudaku, B. (2017, August 8). Historical Background to Contemporary Violent Conflicts in Southern Kaduna and Review of Past Reports on Violent Conflicts in the Area. The Kukah Centre (TKC) and Nigerian Social Responsibility Programme (NSRP) Workshop in Kaduna. 
Johns, E. (2017, June 13). Domestic Aliens: The Zangon Kataf Crisis and the African Concept of Stranger. International Research Group for Transregional \& Emerging Area Studies. Http://iteas.net/domesticaliens-the-zangon-kataf-crisisand-the-african-concept-of-stranger/

Kukah. (2017). From the Valley of Death: Memory, Healing and Inter-group dialogue in Southern Kaduna.

Lamidi, K.O. (2019). Peace Building: Conceptual, Trajectory and Imperative Analyses in the Third World Countries. Canadian Social Sciences, 53-64.

Luka, B. (2016). Inside Zango-Kataf chiefdom, 24 years after killings in natives' battle with Hausa-Fulani settlers. Vanguard Nigeria. https:/www.vanguardngr.com/2016/11/inside-zango-katafchiefdom24-years-killings-natives-battle-hausa-fulanisettlers/

Luka, B. (2017, January 15). Southern Kaduna Crisis Making Sense of Claims and Counterclaims. Vanguard Newspaper.

Omotoso, F. (2010). Federalism, Politics and Governance in Nigeria. In F. Omotoso, A. Agagu, and O. Abegunde (Eds.), Governance, Politics and Policies in Nigeria: An Essay in Honour of Professor Dipo Kolawole: Benin Editions Sonou D’Afrique.

Uroko, F.C. (2018). Readdressing the Ethno-Religious Conflicts in Southern Kaduna, Nigeria in the Light of Abraham-Lot Narrative (Genesis 13:1-18). UJAH, 19(2), 25-43. http://dx.doi./org/10.4314/ujah.v19i2.2 